Article

\title{
Pongamia pinnata L. Leaves Biochar Increased Growth and Pigments Syntheses in Pisum sativum L. Exposed to Nutritional Stress
}

\author{
Sadaf Hashmi ${ }^{1}$, Uzma Younis ${ }^{2}$, Subhan Danish ${ }^{3}$ and Tariq Muhammad Munir ${ }^{4, *(\text { C) }}$ \\ 1 Institute of Pure and Applied Biology, Bahauddin Zakariya University, Multan 60800, Pakistan \\ 2 Department of Botany, University of Central Punjab, Lahore 54000, Pakistan \\ 3 Department of Soil Science, Faculty of Agricultural Sciences and Technology, \\ Bahauddin Zakariya University, Multan 60800, Pakistan \\ 4 Department of Geography, University of Calgary, 2500 University Dr. NW, Calgary, AB T2N 1N4, Canada \\ * Correspondence: tmmunir@ucalgary.ca; Tel.: +1-403-971-5693
}

Received: 9 June 2019; Accepted: 9 July 2019; Published: 11 July 2019

check for updates

\begin{abstract}
Pea (Pisum sativum L.) leaf chlorophyll and pigments syntheses are retarded under nutritional stress. Biochar has the potential to regulate soil nutrient supplies and optimize plant nutrient uptakes. We examine the role of Pongamia pinnata L. waste leaf biochar (PLB) in improving vegetative growth and leaf chlorophyll and accessory pigments of pea exposed to nutritional stress. Three PLB application rates (0, 1, and 2\%) crossed with half (HF), and full NPK fertilizer (FF) recommended doses were applied to sandy soil field-pots (arranged in a completely randomized design). There were significant or maximum increases in plant vegetative or physiological traits, including the fresh or dry, above- and below-ground biomass weights, and photosynthetic pigments (chlorophyll a, chlorophyll b, total chlorophyll, carotenoids, and anthocyanin) in response to a $2 \%$ PLB + FF application $(p=0.002)$. Trait values also responded to $2 \%$ PLB $+\mathrm{HF}$, which signified the nutrient regulatory character of $\operatorname{PLB}(p=0.038)$. The PLB-driven reduction in nutritional stress resulted in diminished lycopene (antioxidant) content $(p=0.041)$. Therefore, we suggest that the soil application of $2 \%$ PLB + FF has the greatest impact on pea vegetative growth and leaf chlorophyll, carotenoids, anthocyanin, and lycopene contents in Pisum sativum L. Further research is recommended to investigate the relationship of PLB with soil nutrient availabilities and plant nutrient concentrations.
\end{abstract}

Keywords: biochar; chlorophyll content; nutritional stress; pea

\section{Introduction}

Domesticated plants play a significant role in food production for fulfilling human hunger [1]. Modern agriculture is feeding 6000 million people, compared to old age hunter-gatherer lifestyle that provided food to only four million [2]. While the world's population is increasing, the production of crops has increased two-fold in the last 40 years, mainly through the use of modern production technologies, inorganic fertilizers, and pesticides [3]. Food demand and supply dynamics [4] have shifted conventional agriculture to the intensive cultivation of crops [5]. The intense (or exhaustive) cultivation of crops has depleted the nutrient concentrations in soil, resulting in fewer plant nutrient supplies (and reduced chlorophyll pigments syntheses) [6]. Reduced chlorophyll synthesis causes crop nutrient deficiency of macro- and micro-nutrients [7]. The compromised nutrient supplies [8] and pigments syntheses would be further exacerbated by the projected accelerated mineralization of soil organic matter (SOM) and the limited availability of moisture under warmer and drier climatic conditions $[9,10]$ of future climate change [11]. While the effects of various inorganic and organic soil amendments are extensively studied [12,13], controlled field-pots experimentation for testing 
Pisum sativum L. waste leaf biochar (PLB) influence on Pisum sativum L.'s chlorophyll pigments syntheses and growth have not been studied, to our knowledge.

Synthesis of a photosynthetic pigment is one of the main processes of plant metabolism, and is strongly influenced by abiotic factors [14] such as soil or plant nutrient availabilities of nitrogen $(\mathrm{N})$, phosphorus $(\mathrm{P})$, and potassium (K) [15]. The accessibility of nutrients is also associated with syntheses of healthy chlorophyll pigments and overall plant growth observed in a range of crop plants, e.g., cowpea $[16,17]$ exposed to water stress $[18,19]$. Nutrient deficiency strongly influences the photosynthetic apparatus structure and function [20]. Therefore, syntheses of pigments such as chlorophylls a and b, and carotenoids and lycopene, are among the indirect indices of crop productivity [21], and their measured values can be used for the proxy of plant nutrient uptakes [21,22] by generating simple regression models [23].

Under nutritional stress, plants accumulate stress ethylene [24]. The stress generating ethylene, when adjacent to the chloroplast, degrades lipids in the cell membrane and activates the chlorophyllase (chlase) gene [25]. Activation of chlorophyllase results in the degradation of chlorophyll, and ultimately plants suffer from chlorosis [25].

Pongamia Pinnata $\mathrm{L}$. leaves are locally available in abundance in the fall season when Pisum sativum $\mathrm{L}$. is cultivated. Therefore, Pongamia Pinnata L. leaves are not only a clean and sustainable source for manufacturing PLB for mineral soil conditioning but also help in maintaining a healthy nutrient balance between soil availability and plant requirement [3]. Additionally, the biomass-sourced biochar is used as an alternative to inorganic fertilizers, and therefore it helps in reducing pollution and decreasing the cost of crop inputs with a better benefit-to-cost ratio.

Biochar is originally an active soil amendment with very high soil pore volume and cation exchange capacity (CEC), and is frequently reported to reduce nutrient stress in soils [26-28]. Biochar production through pyrolysis of different feedstocks and amendments in croplands has already been projected to be a vital option to increase soil organic carbon (SOC) and soil fertility [29-32] and improve ecosystem functioning of biomass and yield productivities [33]. The carbon-rich biochar can enhance soil fertility by improving the nutrient holding capacity of soil [19]. It has low density, large surface area and porosity, and very high cation or anion exchange capacity (negative and positive surface charges), due to the aromatic nature of constituent compounds that make biochar resistant to decomposition [34]. Moreover, the PLB may also contain substantial amounts of active nutrients, for example, $\mathrm{N}$ contained in the biochar may modify soil $\mathrm{N}$ dynamics, thereby affecting soil available $\mathrm{N}$, plant $\mathrm{N}$ assimilation, and biological $\mathrm{N}$ fixation processes $[35,36]$. Additionally, the PLB's fine nature and high porosity can also significantly improve the physical characteristics (e.g., water retention, hydraulic conductivity, and aggregate stability) [37] and chemical properties ( $\mathrm{pH}$, organic carbon, and CEC) of soil [34] that play imperative role in soil conditioning and crop production [38].

As nutrient availability and scarcity are significant issues for farmers, the current study is designed to examine the impacts of Pongamia pinnata L. leaves biochar (PLB) on the growth and photosynthetic pigments of Pisum sativum L. applied with one-half and full dozes of recommended macronutrients. We hypothesize that the application of PLB will increase the growth and photosynthetic pigments in Pisum sativum L. under stress induced by the experimental deficiency of macronutrients. Previous studies have reported strong correlations between photosynthetic pigments and crop growth $[39,40]$.

\section{Materials and Methods}

\subsection{Experimental Site}

We conducted a pot experiment in the Bio Park ( $30^{\circ} 16^{\prime} 06.6^{\prime \prime} \mathrm{N} 71^{\circ} 30^{\prime} 01.9^{\prime \prime}$ E) located near the Institute of Pure and Applied Biology, Bahauddin Zakariya University, Multan, Pakistan, during mid-September to mid-November of 2015. For the pot trial, calcareous soil was collected from alluvium from the Chenab River (Multan, Pakistan). The USDA system classifies this soil as a sandy-loam, hyperthermic, mixed, sodic haplocambid [41]. For measuring the soil pH and electrical conductivity 
(EC), a soil-to-water ratio of 1:1 (w/v) was used to make soil-water suspension (Table 1). The $\mathrm{pH}$ of soil suspension was measured using JENWAY $3510 \mathrm{pH}$ meter, while the EC was recorded using CM-30 ET digital conductivity meter. We followed Olsen and Sommers [42] for available soil P, Nadeem et al. for extractable K [43], and Walkley [44] for soil organic matter determinations.

Table 1. Characteristics of soil, irrigation water, and biochar used in the study *

\begin{tabular}{|c|c|c|c|c|c|c|c|c|}
\hline $\begin{array}{c}\text { Soil } \\
\text { Parameters }\end{array}$ & Units & Values & $\begin{array}{c}\text { Water } \\
\text { Parameters }\end{array}$ & Units & Values & PLB & Units & Values \\
\hline $\mathrm{pH}$ & - & 7.50 & Carbonates & meq $\mathrm{L}^{-1}$ & 0 & $\mathrm{pH}$ & - & 8.15 \\
\hline EC & $\mathrm{d} S \mathrm{~m}^{-1}$ & 0.89 & Bicarbonates & meq $\mathrm{L}^{-1}$ & 5.6 & EC & $\mathrm{dS} \mathrm{m}^{-1}$ & 0.74 \\
\hline $\mathrm{OM}$ & $\%$ & 0.45 & Chloride & meq $\mathrm{L}^{-1}$ & 1.7 & $\begin{array}{c}\text { Total } \\
\text { Phosphorus }\end{array}$ & $\mu \mathrm{g} \mathrm{g}^{-1}$ & 7.31 \\
\hline ON & $\%$ & 0.02 & Sulphate & meq $\mathrm{L}^{-1}$ & 0.8 & Total Potassium & $\mu \mathrm{g} \mathrm{g}^{-1}$ & 56 \\
\hline Extractable P & $\mu \mathrm{g} \mathrm{g}^{-1}$ & 8.91 & $\mathrm{Ca}+\mathrm{Mg}$ & meq $\mathrm{L}^{-1}$ & 4.7 & Ash content & $\%$ & 66.18 \\
\hline \multirow[t]{4}{*}{ Extractable K } & $\mu \mathrm{g} \mathrm{g}^{-1}$ & 101 & $\mathrm{Na}$ & meq $\mathrm{L}^{-1}$ & 3.4 & Volatile matter & $\%$ & 14.39 \\
\hline & & & SAR & $\left(\mathrm{mmol} \mathrm{L}^{-1}\right)^{-1 / 2}$ & 2.22 & Fixed C & $\%$ & 19.43 \\
\hline & & & RSE & meq $\mathrm{L}^{-1}$ & 0.90 & Total N & $\%$ & 0.83 \\
\hline & & & & & & CEC & $\mathrm{mmol}_{\mathrm{c}} \mathrm{kg}^{-1}$ & 249.21 \\
\hline
\end{tabular}

* EC, OM, and ON represent electrical conductivity, organic matter, and organic nitrogen, respectively. $\mathrm{Ca}+\mathrm{Mg}, \mathrm{Na}$, SAR, and RSE represent calcium and magnesium, sodium, sodium adsorption ratio, and residual sodium carbonate, respectively. PLB is Pongamia pinnata L. waste leaf biochar.

\subsection{Experimental Design}

A total of 24 pots ( 6 treatments $\times 4$ replicates) were laid out in a completely randomized design. Each of the various PLB/NPK treatments was thoroughly mixed up with $5 \mathrm{~kg}$ of soil that was air dried and passed through a $2 \mathrm{~mm}$ sieve. The six treatments were developed using three doses of PLB [0\% $(w / w)$ PLB $(0 \mathrm{~g}), 1 \%(w / w)$ PLB $(50 \mathrm{~g})$, and $2 \%(w / w)$ PLB $(100 \mathrm{~g})]$ and two rates of NPK fertilizer [half recommended dose of NPK (HF) and full recommended dose of NPK (FF)]. The NPK fertilizers were sourced from urea, diammonium phosphate, and sulphate of potash, respectively. The treatments were control (HF), HF + 1\%PLB (50 g PLB/5 kg air-dried soil), HF + 2\%PLB (100 g PLB/5 kg air-dried soil), FF, FF + 1\%PLB (50g PLB/5 kg air-dried soil), and FF + 2\%PLB (100g PLB/5 kg air-dried soil). The $\mathrm{N}$ was applied at the rate of (@) $75 \mathrm{~kg} \mathrm{ha}^{-1}$, P @ 120, and K @ $120 \mathrm{~kg} \mathrm{ha}^{-1}$ (recommended fertilizer doses). All $\mathrm{P}$ and $\mathrm{K}$ were applied at the time of sowing, while $\mathrm{N}$ was applied after 15 days of planting.

\subsection{Leaf Biochar Preparation}

The waste leaves of Pongamia pinnata L. were used as biomass for the preparation of PLB in a specially designed pyrolyzer [45]. Briefly, the leaves were air dried, hand-crushed, ground to a size of $\leq 0.45 \mathrm{~mm}$, and pyrolyzed (thermal decomposition) in a pyrolyzer at $380{ }^{\circ} \mathrm{C}$ for $42 \mathrm{~min}$ under semi-anaerobic condition [46]. The thermal decomposition resulted in a carbon-rich solid residue (called char), from which gases and liquids could be released or evaporate. The manufactured PLB was allowed to cool down, and was collected and ground to a size of $\leq 2.0 \mathrm{~mm}$ [47]. The prepared PLB was stored in clean plastic bags to use for this experiment [17].

\subsection{Biochemical Analyses}

PLB was mixed with distilled water in a ratio of 1:20 $(w / v)$ for measuring $\mathrm{pH}$ and EC (Table 1). The $\mathrm{pH}$ of the PLB suspension was measured using JENWAY $3510 \mathrm{pH}$ meter, while the EC was recorded using CM-30 ET digital conductivity meter [46]. Total phosphorus content $\left(7.31 \mu \mathrm{g} \mathrm{g}^{-1}\right)$ was determined by digesting the PLB with the di-acid mixture $\left(\mathrm{HNO}_{3}: \mathrm{HClO}_{4}\right)$ following Jones [48]. Final absorbance was determined at $430 \mathrm{~nm}$ wavelength using UV-VIS spectrophotometer (Model 6305, Jenway, UK). For total potassium content, digested samples were run on a flamephotometer (Jenway, PFP7, Essex, UK). Ash content and the volatile matter were determined by heating PLB in a 
muffle furnace at 550 (aerobically) and $450^{\circ} \mathrm{C}$ (under partially aerobic condition) for $30 \mathrm{~min}$ [49]. Fixed $\mathrm{C}$ was calculated by using equation [50]

$$
\text { Fixed C }=100-(\% \text { Volatile Matter }+\% \text { Ash Content })
$$

Cations and anions in water were determined according to United States Salinity Laboratory Staff (Table 1) [41].

\subsection{Plant Growth and Attributes}

Six seeds of P. sativum L. (variety: PS-810240) were sown in each pot in mid-September, and after 15 days of sowing, two healthy seedlings were maintained in each pot. Standard agronomic practices were adopted throughout the experiment until harvesting (the end of October). We harvested the plants after 45 days of sowing. Fresh and dry weights of plant root and shoot, and the root length, were examined soon after harvesting.

\subsection{Chlorophyll Contents and Accessory Pigments}

The chlorophyll content (chlorophyll $\mathrm{a}, \mathrm{b}$, and total), was analyzed by measuring the absorbance of fresh leaves extract at $663,645,480,537$, and $503 \mathrm{~nm}$ wavelengths. For the extraction of chlorophyll, $80 \%$ acetone was used. Final calculations were made by adapting the following formulas [51]:

$$
\begin{aligned}
& \text { Chlorophyll a }\left(\mathrm{mg} \mathrm{g}^{-1}\right)=12.7(\text { OD 663) }-2.69(\text { OD 645) V / } 1000(\mathrm{~W}) \\
& \text { Chlorophyll b }\left(\mathrm{mg} \mathrm{g}^{-1}\right)=22.9(\mathrm{OD} 645)-2.69(\mathrm{OD} 663) \mathrm{V} / 1000(\mathrm{~W}) \\
& \text { Total Chlorophyll }\left(\mathrm{mg} \mathrm{g}^{-1}\right)=\text { Chlorophyll a + Chlorophyll }
\end{aligned}
$$

For calculation of carotenoids, the following anthocyanin and lycopene equations were used [52-54]:

$$
\begin{gathered}
\text { Carotenoids }\left(\mathrm{mg} \mathrm{g}^{-1}\right)=\mathrm{OD} 480+0.114(\mathrm{OD} 663)-0.638(\mathrm{OD} 645) \\
\text { Anthocyanin }\left(\mu \mathrm{mol} \mathrm{ml} \mathrm{l}^{-1}\right)=(0.08173 \times \mathrm{OD} 537)-(0.00697 \times \mathrm{OD} 645)-(0.002228 \times \mathrm{OD} 663) \\
\text { Lycopene }\left(\mu \mathrm{g} \mathrm{g}^{-1}\right)=(\mathrm{OD} 503-0.0007) \times 30.2 / \mathrm{g} \text { plant tissue }
\end{gathered}
$$

where $\mathrm{OD}$ is optical density in wavelength, $\mathrm{V}$ is the final volume, and $\mathrm{W}$ is fresh leaf $(\mathrm{g})$.

\subsection{Statistical Analyses}

All data met parametric (normal) assumptions of the ANOVA; therefore, all parameters were analyzed by two-way factorial analysis of variance (ANOVA). Treatment means were compared using Tukey-HSD (honestly significant difference) test at $p \leq 0.05$. All data were analyzed using SPSS statistical computer software package (SPSS 18.0. Chicago, IL, USA).

\section{Results}

\subsection{Soil pH and EC}

Main effects of PLB and the two levels of NPK (HF, FF) were significant $(p<0.05$; Table 2). Although the $1 \% \mathrm{PLB}$ and $2 \% \mathrm{PLB}$ were the same $(p>0.05)$, both were higher than the control for soil $\mathrm{pH}(p<0.05)$. At the time of harvesting, soil $\mathrm{pH}$ was higher in response to HF than FF $(p<0.05)$. A maximum increase of $13.5 \%$ in soil $\mathrm{pH}$ was noted where $2 \% \mathrm{PLB}$ was applied compared to the control (No PLB; $p<0.05)$. Use of $2 \%$ PLB enhanced soil EC $(19.4 \%)$ compared to $1 \%$ PLB and control treatments $(p<0.05)$. Similarly, soil EC was higher compared to control (HF) when FF was applied ( $p<$ $0.05)$. A maximum increase of 1.50 -fold in soil EC was noted where $2 \%$ PLB was applied compared to control $(p<0.05)$. 
Table 2. Effect of three rates of the leaf biochar (0,1, and $2 \%)$ under half (HF) and full fertilizer (FF) on the soil $\mathrm{pH}$ and electrical conductivity (EC).

\begin{tabular}{|c|c|c|c|c|c|c|}
\hline \multirow{4}{*}{ Biochar Levels } & \multicolumn{6}{|c|}{ Two Levels of Fertilizers } \\
\hline & \multicolumn{3}{|c|}{ Soil pH } & \multicolumn{3}{|c|}{ Soil ECe $\left(\mathrm{dSm}^{-1}\right)$} \\
\hline & \multicolumn{2}{|c|}{ IE $($ PLB $\times$ F $)$} & \multirow{2}{*}{ ME (PLB) } & \multicolumn{2}{|c|}{ IE $($ PLB $\times$ F $)$} & \multirow{2}{*}{$\begin{array}{l}\text { ME } \\
\text { (PLB) }\end{array}$} \\
\hline & HF & FF & & HF & FF & \\
\hline No PLB (0 g/5 kg soil) & $7.2^{\mathrm{ns}}$ & $7.5^{\mathrm{ns}}$ & $7.4^{\mathrm{B}}$ & $0.20^{\mathrm{ns}}$ & $0.23^{\mathrm{ns}}$ & $0.22^{C}$ \\
\hline 1\%PLB (50 g/5 kg soil) & $8.2^{\mathrm{ns}}$ & $8.3^{\mathrm{ns}}$ & $8.3^{\mathrm{A}}$ & $0.40^{\mathrm{ns}}$ & $0.50 \mathrm{~ns}$ & $0.45^{\mathrm{B}}$ \\
\hline 2\%PLB (100 g/5 kg soil) & $8.4^{\mathrm{ns}}$ & $8.4^{\mathrm{ns}}$ & $8.4^{\mathrm{A}}$ & $0.50^{\mathrm{ns}}$ & $0.60 \mathrm{~ns}$ & $0.55^{\mathrm{A}}$ \\
\hline $\mathrm{ME}(\mathrm{F})$ & $7.9^{\mathrm{B}}$ & $8.1^{\mathrm{A}}$ & & $0.36^{\mathrm{B}}$ & $0.43^{\mathrm{A}}$ & \\
\hline
\end{tabular}

Different letters in a row or column showing a statistical difference at $p \leq 0.05$, compared with Tukey-HSD (honestly significant difference) test. Non-significant interaction has "ns" superscript. ME = main effect, $\mathrm{IE}=$ interactive effect, $\mathrm{F}=$ fertilizers rate, $\mathrm{PLB}=$ Pongamia pinnata $\mathrm{L}$. leaves biochar.

\subsection{Stem and Root Length}

Both main and interactive effects of PLB and F were higher than the control for stem and root lengths of Pisum sativum L $(p<0.05)$. For the stem length, FF $+2 \%$ PLB was higher than all treatments $(p<0.05)$. An increase was also noted in stem length where FF $+1 \%$ PLB was applied compared to control $(p<0.05)$. Application of HF $+2 \%$ PLB and control (FF) were the same for stem length $(p>0.05$; Figure 1). The maximum increase in stem length $(60.0 \%)$ was noted in response to FF $+2 \% \mathrm{PLB}$ compared to control (FF; $p<0.05)$. In the case of root length, no change was observed where HF and FF were applied without PLB $(p>0.05)$. Application of HF $+2 \%$ PLB decreased root length compared to HF $+1 \%$ PLB application $(p<0.05)$. However, FF $+1 \%$ PLB and FF $+2 \%$ PLB were the same for root length $(p>0.05)$. Reductions of 34.4 and $33.9 \%$ in root length were noted in responses to FF $+2 \%$ PLB and $\mathrm{HF}+2 \% \mathrm{PLB}$, respectively, compared to those in responses to FF and HF, respectively $(p<0.05)$.

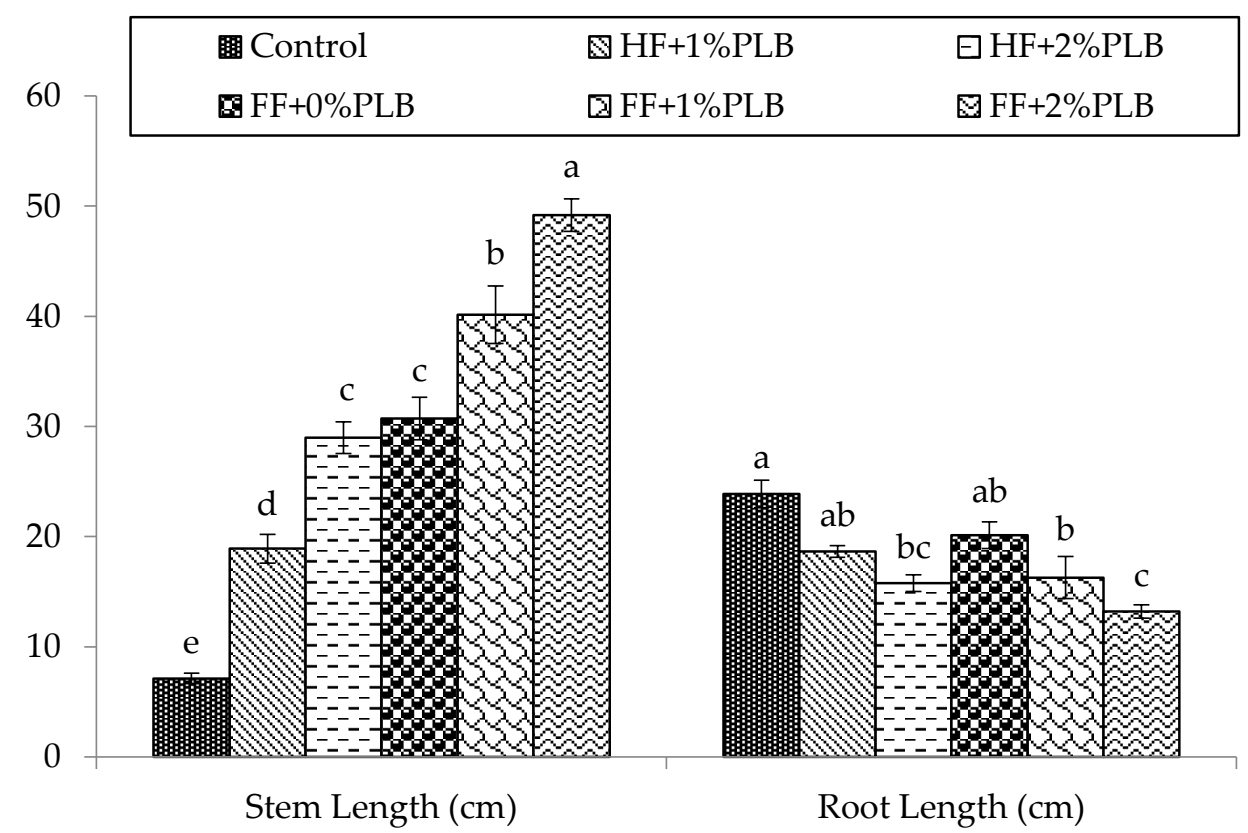

Figure 1. Effect of Pongamia pinnata L. leaves biochar (PLB 0, 1 and 2\%) under HF and FF on the stem and root lengths of Pisum sativum L. Bars should be compared within a group (stem length or root length). Bar heights are different when there are no letters $(\mathrm{a}, \mathrm{b}, \mathrm{c}, \mathrm{d})$ are common $(p<0.05)$. 


\subsection{Plants Fresh and Dry Weight}

Both main and interactive effects of PLB and F were the same for plant fresh and dry weights $(p<0.05)$. Application of FF $+2 \% \mathrm{PLB}$ and $\mathrm{HF}+2 \% \mathrm{PLB}$ increased the fresh and dry weights of plants compared to HF and FF ( $p<0.05$; Figure 2). Likewise, FF $+1 \%$ PLB and HF $+1 \%$ PLB were higher than the control or HF and FF $(p<0.05)$. Application of FF also increased the fresh and dry weights compared to those in response to HF $(p<0.05)$. Maximum increases of 95.9 and $94.5 \%$ in fresh and dry weights of plants were noted when FF $+2 \%$ PLB was applied (in comparison to control or FF) $(p<0.05)$.

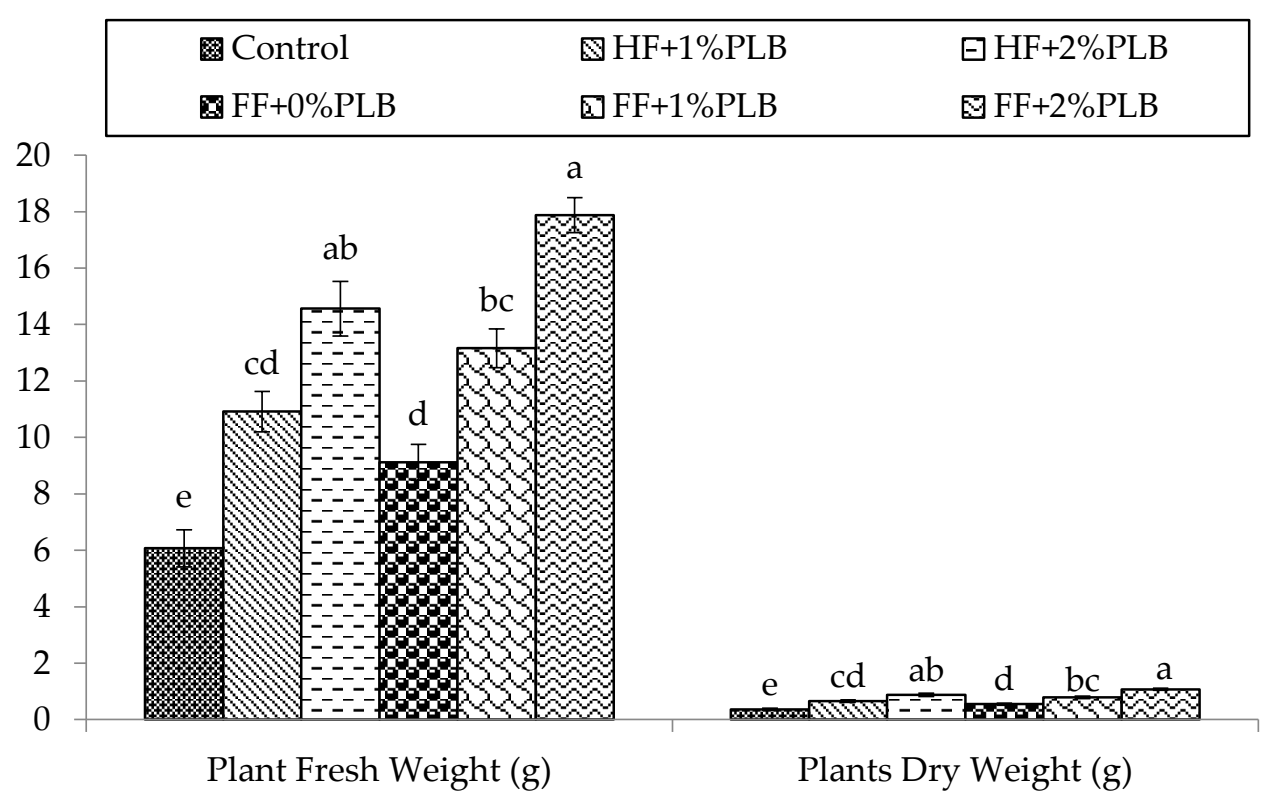

Figure 2. Effect of Pongamia pinnata L. leaves biochar (PLB 0, 1 and 2\%) under HF and FF on Pisum satioum L. plants fresh and dry weight. Bars should be compared within a group (plant fresh weight or plant dry weight). Bar heights are different when there are no letters $(a, b, c, d, e)$ are common $(p<0.05)$.

\subsection{Root Fresh and Dry Weight}

Both main and interactive effects of PLB and F differed for root fresh and dry weights $(p<0.05)$. Application of FF $+2 \% \mathrm{PLB}$ and $\mathrm{HF}+2 \% \mathrm{PLB}$ were the same, but both were higher than the control and HF and FF applications ( $p<0.05$; Figure 3$)$. Likewise, the FF $+1 \%$ PLB and HF $+1 \%$ PLB were similar to each other or HF and FF applications $(p>0.05)$. The maximum increases of 50.6 and $51.0 \%$ in fresh and dry weights of roots were noted compared to control (FF) where FF $+2 \%$ PLB was applied $(p<0.05)$.

\subsection{Chlorophyll Contents}

Main and interactive effects of PLB and F were different on chlorophyll contents $(p<0.05$; Table 3$)$. For chlorophylls $a$ and $b$, the FF $+2 \% \mathrm{PLB}$ and HF $+2 \% \mathrm{PLB}$ were the same, but both increased the pigments values compared to the values in control conditions $(p<0.05)$. The FF $+1 \%$ PLB application increased the chlorophyll $\mathrm{a}$ and $\mathrm{b}$ contents more than in HF+1\%PLB treatment. The HF $+1 \% \mathrm{PLB}$ and FF were the same $(p>0.05)$, but both increased chlorophyll a and $\mathrm{b}$ contents compared to control $(p<0.05)$. The maximum increases of 45.6 and $50.0 \%$ in chlorophyll a and $\mathrm{b}$ contents (respectively) were noted when FF $+2 \%$ PLB was applied $(p<0.05)$. The FF $+2 \%$ PLB increased total chlorophyll more than all other treatments $(p<0.05)$. The HF $+2 \% \mathrm{PLB}$ and FF $+2 \% \mathrm{PLB}$ were the same, but both increased the total chlorophyll contents more than in the control condition $(p<0.05$; Table 3). Additionally, $\mathrm{FF}+2 \% \mathrm{PLB}$ and FF increased the synthesis of total chlorophyll contents compared to control $(p<0.05)$. Overall, the FF $+2 \%$ PLB increased total chlorophyll content by $98.7 \%$, whose value was higher than those in all other treatments $(p<0.05)$. 


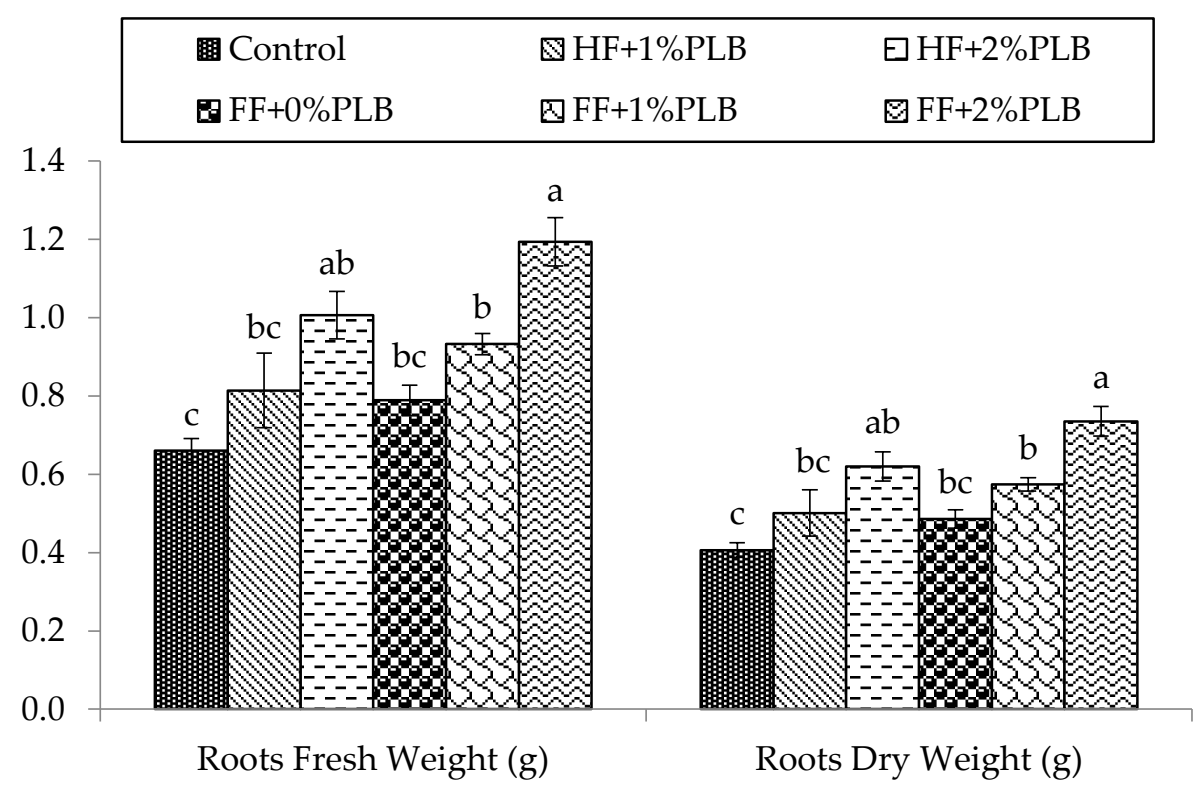

Figure 3. Effect of Pongamia pinnata L. leaves biochar (PLB 0, 1, and 2\%) under HF and FF on Pisum sativum L. roots fresh and dry weights. Bars should be compared within a group (root fresh weight or root dry weight). Bar heights are different when there are no letters $(a, b, c)$ are common $(p<0.05)$.

Table 3. Effect of variable rates of biochar $(0,1$, and $2 \%)$ under HF and FF on the synthesis of the pigments in Pisum sativum L.

\begin{tabular}{|c|c|c|c|c|c|c|}
\hline \multirow{3}{*}{$\begin{array}{c}\text { Various Levels of } \\
\text { Biochar }\end{array}$} & \multicolumn{6}{|c|}{ Various Levels of Fertilizers } \\
\hline & \multicolumn{3}{|c|}{ Chlorophyll a (mg/g) } & \multicolumn{3}{|c|}{ Chlorophyll b (mg/g) } \\
\hline & \multicolumn{2}{|c|}{ IE $($ PLB $\times$ F $)$} & ME (PLB) & \multicolumn{2}{|c|}{ IE $(P L B \times F)$} & ME (PLB) \\
\hline No PLB (0 g/5 kg soil) & $0.058 \pm 0.005^{\mathrm{d}}$ & $0.116 \pm 0.003^{c}$ & $0.087^{\mathrm{C}}$ & $0.051 \pm 0.007^{\mathrm{d}}$ & $0.106 \pm 0.003^{c}$ & $0.079^{\mathrm{C}}$ \\
\hline 1\%PLB (50 g/5 kg soil) & $0.129 \pm 0.003^{c}$ & $0.146 \pm 0.005^{b}$ & $0.138^{\mathrm{B}}$ & $0.119 \pm 0.003^{c}$ & $0.139 \pm 0.007^{b}$ & $0.129^{\mathrm{B}}$ \\
\hline 2\%PLB (100 g/5 kg soil) & $0.158 \pm 0.002^{a b}$ & $0.169 \pm 0.013^{a}$ & $0.163^{\mathrm{A}}$ & $0.150 \pm 0.003^{a b}$ & $0.159 \pm 0.011^{a}$ & $0.154 \mathrm{~A}$ \\
\hline $\mathrm{ME}(\mathrm{F})$ & \multicolumn{3}{|c|}{ Total chlorophyll (mg/g) } & \multicolumn{3}{|c|}{ Carotenoids (mg/g) } \\
\hline No PLB (0 g/5 kg soil) & $0.109 \pm 0.012^{\mathrm{e}}$ & $0.222 \pm 0.006^{\mathrm{d}}$ & $0.166^{\mathrm{C}}$ & $0.090 \pm 0.010^{f}$ & $0.191 \pm 0.005^{\mathrm{e}}$ & $0.141^{\mathrm{C}}$ \\
\hline 1\%PLB (50 g/5 kg soil) & $0.248 \pm 0.006^{c}$ & $0.285 \pm 0.012^{b}$ & $0.267^{\text {B }}$ & $0.220 \pm 0.004^{d}$ & $0.278 \pm 0.010^{c}$ & $0.249^{\mathrm{B}}$ \\
\hline 2\%PLB (100 g/5 kg soil) & $0.317 \pm 0.005^{\mathrm{ab}}$ & $0.328 \pm 0.024^{\mathrm{a}}$ & $0.323^{\mathrm{A}}$ & $0.251 \pm 0.004^{b}$ & $0.306 \pm 0.016^{\mathrm{a}}$ & $0.278^{\mathrm{A}}$ \\
\hline $\operatorname{ME}(\mathrm{F})$ & $0.225^{\mathrm{B}}$ & $0.278^{\mathrm{A}}$ & & $0.187^{\mathrm{B}}$ & $0.258^{\mathrm{A}}$ & \\
\hline $\mathrm{ME}(\mathrm{F})$ & $0.015^{\mathrm{B}}$ & $0.017^{\mathrm{A}}$ & & $0.031^{\mathrm{B}}$ & $0.045^{\mathrm{A}}$ & \\
\hline
\end{tabular}

Significance letters should be compared only between PLB rates in a column. Capital superscripts are used for main effects. Lowercase superscripts are used for interactive effects. Values with different letters in a column are statistically different at $p \leq 0.05$, compared using Tukey-HSD test. ME $=$ main effect, $\mathrm{IE}=$ interactive effect, $\mathrm{F}=$ fertilizers rates, $\mathrm{PLB}=$ Pongamia pinnata $\mathrm{L}$. leaves biochar.

\subsection{Carotenoids, Anthocyanin, and Lycopene}

Both main and interactive effects were higher than the control for carotenoids, lycopene, and anthocyanin syntheses in Pisum sativum L ( $p<0.05$; Table 3). Application of FF $+2 \%$ PLB increased the synthesis of carotenoids more than those in responses to the rest of the treatments $(p<0.05)$. Similarly, HF $+2 \%$ PLB synthesized more carotenoids compared to FF $+1 \% \mathrm{PLB}, \mathrm{HF}+1 \% \mathrm{PLB}, \mathrm{FF}$, and control (HF) treatments $(p<0.05)$. It was observed that the application of HF $+1 \% \mathrm{PLB}$ and FF also gave greater carotenoids syntheses comparative to control $(p<0.05)$. A maximum increase of $60.2 \%$ in carotenoids was noted compared to control (FF) where FF $+2 \%$ PLB was applied $(p<0.05)$. 
In the case of anthocyanin, FF $+2 \% \mathrm{PLB}$ increased pigment synthesis more than those in responses to other treatments $(p<0.05$; Table 3$)$. Application of HF $+2 \%$ PLB and FF $+1 \%$ PLB were the same, but both increased the synthesis of anthocyanin compared to the synthesis under the control condition. Similarly, HF $+1 \%$ PLB and FF were the same for anthocyanin production $(p<0.05)$. A maximum increase of $33.3 \%$ in anthocyanin synthesis was noted compared to control (FF) where FF $+2 \%$ PLB was applied $(p<0.05)$. For lycopene, control treatments showed greater synthesis among all the treatments. We noted decreasing levels of lycopene contents in response to increasing levels of PLB (1-2\%) and fertilizer $(p<0.05)$. HF $+1 \%$ PLB and FF were the same for lycopene contents. The highest reduction in lycopene content was noted compared to control (HF) where FF $+2 \%$ PLB was applied $(p<0.05)$.

\section{Discussion}

In the current study, the addition of PLB as a soil amendment increased the $\mathrm{pH}$ and EC of aridic calcareous soil $(p<0.05)$. The increases in soil $\mathrm{pH}$ and EC have been frequently reported in pot or field studies involving the addition of biochar sourced from a variety of feedstocks [45-47,49,55,56] or plant leaves [57]. Biochar-driven increases in soil $\mathrm{pH}, \mathrm{EC}$, and nutrient retention have also been reported in aridisols (mixed haplocambids) when applied with switchgrass biochar soil amendment. These increases could be due to the greater surface area (or CEC), ash content (Table 1, and porosity of PLB [56,58], and rich chemistry and nutrient contents of the original leaf feedstock [59]. Moreover, increasing pyrolysis temperature from $2500{ }^{\circ} \mathrm{C}$ to $500^{\circ} \mathrm{C}$ was related to increasing soil pH, EC, and $\mathrm{NO}_{3}-\mathrm{N}$ retention $[56,58,60]$. These relationships are comparable to the soil $\mathrm{pH}$ and $\mathrm{EC}$ increases $(13.5 \%$ and $19.4 \%$, respectively) we observed in this study where PLB was prepared by pyrolyzing leaves at $380^{\circ} \mathrm{C}$.

Root and shoot lengths and fresh and dry weights of root and plant had the lowest values in control (no PLB + HF) and were reported to be due to inadequate supplies of nutrients-a crucial factor responsible for weak growth of crops [61]. While the NPK stress played an important role in the reduction of root and shoot dry weights, the leaf chlorophyll content in HF was also at its minimum [62]. Significant increases in root and shoot lengths, and fresh and dry weighs of root and plant (exposed to nutritional stress) in responses to PLB addition in this study, are comparable to the commonly reported increases in plant growth parameters in responses to the soil additions of a variety of biochar [63].

The elongation (or better coverage of roots) in PLB-amended rhizosphere in our study supports an earlier mesocosm study that concluded that the addition of biochar (charcoal fines from mixed-deciduous wood in this case) to the rhizosphere effectively elongates the plant roots [64]. Addition of biochar to aridic calcareous soil very likely increases total pore volume [65], decreases bulk density [66], and enhances cation exchange capacity (CEC) of soil system [66]. The decreasing bulk density and increasing porosity, $\mathrm{CEC}$, and nutrient holding capacity in response to increasing black carbon (or biochar) in soil were also verified in an x-ray absorption microscopic study [34,67].

Biochar's high affinities to sorb the nutrient elements present in soil and offset the losses (or leaching) of nutrients from the soil system [68] could be the underlying reason for supporting the elongation of roots [67] found in our study. Other reasons could be the possible biochar's surface oxidation by biotic and abiotic factors, resulting in the development of net-negative charges, which may contribute to the sorption of nutrients, offsetting of nutrients losses, and enhancement of soil nutrients availabilities [17,69]. Moreover, the possible presences of carboxylic- $\mathrm{C}$ and aromatic-OH functional groups on the PLB surfaces lead to high sorption of nutrients [70]. We did not monitor soil or plant nutrient exchanges, and strongly recommend including such measurements in future related studies.

Increasing crop yield traits were observed in response to increasing PLB application to calcareous sandy soil. Increases in crop yield trait values were found to be controlled by the biochar amendment in the soil in a variety of studies [71]. Besides the potential improvements in plant-growth-friendly chemical and physical properties of soil (discussed above), biochar can enhance soil biological properties $[70,72]$. Biochar can contribute to better colonization of plant growth promoting bacteria 
(PGPR) [26]. The PGPR act as an allied factor for better availability of nutrients and contribute to increasing chlorophyll pigments in wheat plant [73].

Biochar is well known to optimize the availabilities of water and nutrients to roots, resulting in significant increases in pigments syntheses and assimilations in plant leaves [74]; however, contrary findings are not uncommon [73]. These findings are attributed to contrasting feedstocks, soils, and environmental conditions [73,74].

Under nutritional stress, plants accumulate stress ethylene [24]. The stress generating ethylene, when adjacent to the chloroplast, degrades lipids in the cell membrane and activates chlorophyllase (chlase) gene [25]. Activation of chlorophyllase results in the degradation of chlorophyll, and ultimately plant suffers from chlorosis [25]. In the current study, without PLB (and nutritional stress), the chlorophyll contents were also low, which might be due to the production of ethylene, which was not investigated in this study. A significant improvement in chlorophyll contents in response to PLB application confirmed the significance of applied PLB for mitigation of nutritional stress in plants.

Increases in chlorophyll contents and yield attributes in responses to increasing timber-waste biochar in soil were also reported in a biochar trial on wheat crop under greenhouse [75] and laboratory [26] conditions. Similarly, in the current study, the chlorophyll a, chlorophyll b, total chlorophyll, carotenoids, and anthocyanin were significantly increased in response to a higher application rate of PLB ( $2 \%$; Table 3$)$. We did not find an exactly comparable study of same feedstock and crop; our findings can be compared to pot [75] and field [26] studies' findings. Moreover, a reduction (or antagonistic relation) of plant lycopene contents in response to PLB application also indicates the mitigation of the experimental nutritional stress in this study.

\section{Conclusions}

Soil application of Pongamia pinnata L. leaf biochar (PLB) (at the rate of $2 \% \mathrm{PLB}+\mathrm{FF}$ or $2 \% \mathrm{PLB}+$ $\mathrm{HF}$ ) increased plant yield traits including stem and root lengths, and fresh and dry weights of aboveand below-ground biomasses of Pisum sativum L. exposed to nutritional stress $(p<0.05)$. Increases in all studied plant pigments including chlorophylls $\mathrm{a}, \mathrm{b}$, and total, and carotenoids and anthocyanin (except lycopene), were also observed $(p<0.05)$. Therefore, we suggest that the soil addition of PLB increases plant yield traits values in Pisum sativum L.; however, the underlying soil-plant nutrient exchanges should be thoroughly investigated in comparable studies in future.

Author Contributions: Conceptualization and Formal analysis: U.Y., S.H. and S.D.; Investigation: S.H. and S.D.; Methodology, S.D., U.Y., and S.H.; Writing: S.D., S.H. and T.M.M.; Writing-Review and Editing: T.M.M. Research.

Funding: This research was funded by the Institute of Pure and Applied Biology, Bahauddin Zakariya University, Multan, Pakistan. APC was funded by Tariq M. Munir.

Conflicts of Interest: The authors declare no conflict of interest.

\section{References}

1. Loring, P.A.; Gerlach, S.C. Food, culture, and human health in alaska: An integrative health approach to food security. Environ. Sci. Policy 2009, 12, 466-478. [CrossRef]

2. Mackellar, F.L. On human carrying capacity: A review essay on joel cohen's: How many people can the earth support? Popul. Dev. Rev. 1996, 22, 145-156. [CrossRef]

3. Tilman, D.; Cassman, K.G.; Matson, P.A.; Naylor, R.; Polasky, S. Agricultural sustainability and intensive production practices. Nature 2002, 418, 671-677. [CrossRef] [PubMed]

4. Mechlem, K. Food security and the right to food in the discourse of the united nations. Eur. Law J. 2004, 10, 631-648. [CrossRef]

5. Holzschuh, A.; Steffan-Dewenter, I.; Kleijn, D.; Tscharntke, T. Diversity of flower-visiting bees in cereal fields: Effects of farming system, landscape composition and regional context. J. Appl. Ecol. 2007, 44, 41-49. [CrossRef] 
6. Zhao, D.; Reddy, K.R.; Kakani, V.; Read, J.; Carter, G. Corn (zea mays 1.) growth, leaf pigment concentration, photosynthesis and leaf hyperspectral reflectance properties as affected by nitrogen supply. Plant Soil 2003, 257, 205-218. [CrossRef]

7. Khan, M.N.; Siddiqui, M.H.; Mohammad, F.; Naeem, M.; Khan, M.M.A. Calcium chloride and gibberellic acid protect linseed (linum usitatissimum 1.) from nacl stress by inducing antioxidative defence system and osmoprotectant accumulation. Acta Physiol. Plant. 2010, 32, 121. [CrossRef]

8. Munir, T.M.; Khadka, B.; Xu, B.; Strack, M. Mineral nitrogen and phosphorus pools affected by water table lowering and warming in a boreal forested peatland. Ecohydrology 2017, 10, e1893. [CrossRef]

9. Munir, T.M.; Perkins, M.; Kaing, E.; Strack, M. Carbon dioxide flux and net primary production of a boreal treed bog: Responses to warming and water-table-lowering simulations of climate change. Biogeosciences 2015, 12, 1091-1111. [CrossRef]

10. Bechtold, M.; De Lannoy, G.J.M.; Koster, R.D.; Reichle, R.H.; Mahanama, S.; Munir, T.M.; Bourgault, M.A.; Brümmer, C.; Burdun, I.; Desai, A.R. Peat-clsm: A specific treatment of peatland hydrology in the nasa catchment land surface model. J. Adv. Model. Earth Syst. 2019, 11. [CrossRef]

11. Munir, T.M. Peatland Biogeochemistry and Plant Productivity Responses to Field-Based Hydrological and Temperature Simulations of Climate Change. Ph.D. Thesis, University of Calgary, Calgary, AB, Canada, 2015.

12. Jaipaul, S.S.; Dixit, A.K.; Sharma, A. Growth and yield of capsicum (capsicum annum 1.) and garden pea (pisum sativum 1.) as influenced by organic manures and biofertilizers. Indian J. Agric. Sci. 2011, 81, 637-642.

13. Schüler, C.; Pikny, J.; Nasir, M.; Vogtmann, H. Effects of composted organic kitchen and garden waste on mycosphaerella pinodes (berk, et blox) vestergr., causal organism of foot rot on peas (pisum sativum L.). Biol. Agric. Hortic. 1993, 9, 353-360. [CrossRef]

14. Kalaji, H.M.; Bąba, W.; Gediga, K.; Goltsev, V.; Samborska, I.A.; Cetner, M.D.; Dimitrova, S.; Piszcz, U.; Bielecki, K.; Karmowska, K. Chlorophyll fluorescence as a tool for nutrient status identification in rapeseed plants. Photosynth. Res. 2018, 136, 329-343. [CrossRef] [PubMed]

15. Baltzer, J.L.; Thomas, S.C. Leaf optical responses to light and soil nutrient availability in temperature deciduous trees. Am. J. Bot. 2005, 92, 214-223. [CrossRef] [PubMed]

16. Abid, M.; Danish, S.; Zafar-ul-Hye, M.; Shaaban, M.; Iqbal, M.M.; Rehim, A.; Qayyum, M.F.; Naqqash, M.N. Biochar increased photosynthetic and accessory pigments in tomato (solanum lycopersicum 1.) plants by reducing cadmium concentration under various irrigation waters. Environ. Sci. Pollut. R. 2017, 24, 22111-22118. [CrossRef] [PubMed]

17. Younis, U.; Qayyum, M.F.; Shah, M.H.R.; Danish, S.; Shahzad, A.N.; Malik, S.A.; Mahmood, S. Growth, survival, and heavy metal (cd and ni) uptake of spinach (spinacia oleracea) and fenugreek (trigonella corniculata) in a biochar-amended sewage-irrigated contaminated soil. J. Plant Nutr. Soil Sci. 2015, 178, 209-217. [CrossRef]

18. Rizwan, M.; Ali, S.; Abbas, T.; Adrees, M.; Zia-ur-Rehman, M.; Ibrahim, M.; Abbas, F.; Qayyum, M.F.; Nawaz, R. Residual effects of biochar on growth, photosynthesis and cadmium uptake in rice (oryza sativa 1.) under cd stress with different water conditions. J. Environ. Manag. 2018, 206, 676-683. [CrossRef]

19. Woolf, D.; Amonette, J.E.; Street-Perrott, F.A.; Lehmann, J.; Joseph, S. Sustainable biochar to mitigate global climate change. Nat. Commun. 2010, 1, 56. [CrossRef]

20. Kalaji, H.M.; Oukarroum, A.; Alexandrov, V.; Kouzmanova, M.; Brestic, M.; Zivcak, M.; Samborska, I.A.; Cetner, M.D.; Allakhverdiev, S.I.; Goltsev, V. Identification of nutrient deficiency in maize and tomato plants by in vivo chlorophyll a fluorescence measurements. Plant Physiol. Biochem. 2014, 81, 16-25. [CrossRef]

21. Bojović, B.; Stojanović, J. Chlorophyll and carotenoid content in wheat cultivars as a function of mineral nutrition. Arch. Biol. Sci. 2005, 57, 283-290. [CrossRef]

22. Cendrero-Mateo, M.P.; Carmo-Silva, A.E.; Porcar-Castell, A.; Hamerlynck, E.P.; Papuga, S.A.; Moran, M.S. Dynamic response of plant chlorophyll fluorescence to light, water and nutrient availability. Funct. Plant Biol. 2015, 42, 746-757. [CrossRef]

23. Munir, T.M.; Khadka, B.; Xu, B.; Strack, M. Partitioning forest-floor respiration into source based emissions in a boreal forested bog: Responses to experimental drought. Forests 2017, 8, 75. [CrossRef]

24. Khan, M.I.; Trivellini, A.; Fatma, M. Role of ethylene in responses of plants to nitrogen availability. Front. Plant Sci. 2015, 6, 927. [CrossRef]

25. Michaud, M.; Jouhet, J. Lipid trafficking at membrane contact sites during plant development and stress response. Front. Plant Sci. 2019, 10, 2. [CrossRef] [PubMed] 
26. Zafar-ul-Hye, M.; Danish, S.; Abbas, M.; Ahmad, M.; Munir, T.M. ACC deaminase producing pgpr bacillus amyloliquefaciens and agrobacterium fabrum along with biochar improve wheat productivity under drought stress. Agronomy 2019, 9, 343. [CrossRef]

27. Dela Rosa, J.M.; Paneque, M.; Hilber, I.; Blum, F.; Knicker, H.E.; Bucheli, T.D. Assessment of polycyclic aromatic hydrocarbons in biochar and biochar-amended agricultural soil from southern spain. J. Soils Sediments 2016, 16, 557-565. [CrossRef]

28. Wacal, C.; Ogata, N.; Basalirwa, D.; Handa, T.; Sasagawa, D.; Acidri, R.; Ishigaki, T.; Kato, M.; Masunaga, T.; Yamamoto, S.; et al. Growth, seed yield, mineral nutrients and soil properties of sesame (sesamum indicum 1.) as influenced by biochar addition on upland field converted from paddy. Agronomy 2019, 9, 55. [CrossRef]

29. Kung, C.-C.; Kong, F.; Choi, Y. Pyrolysis and biochar potential using crop residues and agricultural wastes in china. Ecol. Indic. 2015, 51, 139-145. [CrossRef]

30. Scotti, R.; D’ascoli, R.; Gonzalez Caceres, M.; Bonanomi, G.; Sultana, S.; Cozzolino, L.; Scelza, R.; Zoina, A.; Rao, M. Combined use of compost and wood scraps to increase carbon stock and improve soil quality in intensive farming systems. Eur. J. Soil Sci. 2015, 66, 463-475. [CrossRef]

31. Scotti, R.; Pane, C.; Spaccini, R.; Palese, A.M.; Piccolo, A.; Celano, G.; Zaccardelli, M. On-farm compost: A useful tool to improve soil quality under intensive farming systems. Appl. Soil Ecol. 2016, 107, 13-23. [CrossRef]

32. Laird, D.A. The charcoal vision: A win-win-win scenario for simultaneously producing bioenergy, permanently sequestering carbon, while improving soil and water quality. Agron. J. 2008, 100, 178-181. [CrossRef]

33. Biederman, L.A.; Harpole, W.S. Biochar and its effects on plant productivity and nutrient cycling: A meta-analysis. GCB Bioenergy 2013, 5, 202-214. [CrossRef]

34. Liang, B.; Lehmann, J.; Solomon, D.; Kinyangi, J.; Grossman, J.; O’neill, B.; Skjemstad, J.; Thies, J.; Luizao, F.; Petersen, J. Black carbon increases cation exchange capacity in soils. Soil Sci. Soc. Am. J. 2006, 70, 1719-1730. [CrossRef]

35. Rondon, M.A.; Lehmann, J.; Ramírez, J.; Hurtado, M. Biological nitrogen fixation by common beans (phaseolus vulgaris 1.) increases with bio-char additions. Biol. Fertil. Soils 2007, 43, 699-708. [CrossRef]

36. Saarnio, S.; Heimonen, K.; Kettunen, R. Biochar addition indirectly affects $\mathrm{N}_{2} \mathrm{O}$ emissions via soil moisture and plant N uptake. Soil Biol. Biochem. 2013, 58, 96-106. [CrossRef]

37. Liu, H.; Ju, Z.; Bachmann, J.; Horton, R.; Ren, T. Moisture-dependent wettability of artificial hydrophobic soils and its relevance for soil water desorption curves. Soil Sci. Soc. Am. J. 2012, 76, 342-349. [CrossRef]

38. Steiner, C.; Teixeira, W.G.; Lehmann, J.; Nehls, T.; de Macêdo, J.L.V.; Blum, W.E.H.; Zech, W. Long term effects of manure, charcoal and mineral fertilization on crop production and fertility on a highly weathered central amazonian upland soil. Plant Soil 2007, 291, 275-290. [CrossRef]

39. Ashraf, M.; Harris, P. Photosynthesis under stressful environments: An overview. Photosynthetica 2013, 51, 163-190. [CrossRef]

40. Amuthavalli, P.; Sivasankaramoorthy, S. Effect of salt stress on the growth and photosynthetic pigments of pigeon pea (cajanus cajan 1.). J. Appl. Pharm. Sci. 2012, 2, 131. [CrossRef]

41. United States Salinity Laboratory Staff. Diagnosis and Improvement of Saline and Alkali Soils; USDA Handbook 60; United States Department of Agriculture: Washington, DC, USA, 1954.

42. Olsen, S.R.; Sommers, L.E. Phosphorus. In Method of Soil Analysis, 2nd ed.; American Society of Agronomy: Madison, WI, USA, 1982; pp. 403-430.

43. Nadeem, S.M.; Zahir, Z.A.; Naveed, M.; Arshad, M. Rhizobacteria containing acc-deaminase confer salt tolerance in maize grown on salt-affected fields. Can. J. Microbiol. 2009, 55, 1302-1309. [CrossRef]

44. Walkley, A. An examination of methods for determining organic carbon and nitrogen in soils. J. Agric. Sci. 1935, 25, 598-609. [CrossRef]

45. Qayyum, M.F.; Abid, M.; Danish, S.; Saeed, M.K.; Ali, M.A. Effects of various biochars on seed germination and carbon mineralization in an alkaline soil. Pak. J. Agric. Sci. 2015, 51, 977-982.

46. Singh, B.; Singh, B.P.; Cowie, A.L. Characterisation and evaluation of biochars for their application as a soil amendment. Aust. J. Soil Res. 2010, 48, 516-525. [CrossRef]

47. Suthar, R.G.; Wang, C.; Nunes, M.C.N.; Chen, J.; Sargent, S.A.; Bucklin, R.A.; Gao, B. Bamboo biochar pyrolyzed at low temperature improves tomato plant growth and fruit quality. Agriculture 2018, 8, 153. [CrossRef] 
48. Jones, J.B., Jr.; Wolf, B.; Mills, H.A. Plant Analysis Handbook: A Practical Sampling, Preparation, Analysis, and Interpretation Guide; Micro-Macro Publishing, Inc.: Athens, GA, USA, 1991.

49. Kloss, S.; Zehetner, F.; Dellantonio, A.; Hamid, R.; Ottner, F.; Liedtke, V.; Schwanninger, M.; Gerzabek, M.H.; Soja, G. Characterization of slow pyrolysis biochars: Effects of feedstocks and pyrolysis temperature on biochar properties. J. Environ. Qual. 2012, 41, 990-1000. [CrossRef] [PubMed]

50. Noor, N.M.; Shariff, A.; Abdullah, N. Slow pyrolysis of cassava wastes for biochar production and characterization. Iran. J. Energy Environ. 2012, 3, 60-65.

51. Arnon, D.I. Copper enzymes in isolated chloroplasts. Polyphenoloxidase in beta vulgaris. Plant Physiol. 1949, 24, 1-15. [CrossRef] [PubMed]

52. Kirk, J.; Allen, R. Dependence of chloroplast pigment synthesis on protein synthesis: Effect of actidione. Biochem. Biophys. Res. Commun. 1965, 21, 523-530. [CrossRef]

53. Sims, D.A.; Gamon, J.A. Relationships between leaf pigment content and spectral reflectance across a wide range of species, leaf structures and developmental stages. Remote Sens. Environ. 2002, 81, 337-354. [CrossRef]

54. Rao, A.; Waseem, Z.; Agarwal, S. Lycopene content of tomatoes and tomato products and their contribution to dietary lycopene. Food Res. Int. 1998, 31, 737-741. [CrossRef]

55. Antonious, G.; Turley, E.; Dawood, M. Ascorbic acid, sugars, phenols, and nitrates concentrations in tomato grown in animal manure amended soil. Agriculture 2019, 9, 94. [CrossRef]

56. Ippolito, J.; Stromberger, M.; Lentz, R.; Dungan, R. Hardwood biochar influences calcareous soil physicochemical and microbiological status. J. Environ. Qual. 2014, 43, 681-689. [CrossRef] [PubMed]

57. Mary, G.S.; Sugumaran, P.; Niveditha, S.; Ramalakshmi, B.; Ravichandran, P.; Seshadri, S. Production, characterization and evaluation of biochar from pod (pisum sativum), leaf (brassica oleracea) and peel (citrus sinensis) wastes. Int. J. Recycl. Org. Waste Agric. 2016, 5, 43-53. [CrossRef]

58. Ippolito, J.; Novak, J.; Busscher, W.; Ahmedna, M.; Rehrah, D.; Watts, D. Switchgrass biochar affects two aridisols. J. Environ. Qual. 2012, 41, 1123-1130. [CrossRef] [PubMed]

59. Lentz, R.D.; Ippolito, J.A. Biochar and manure affect calcareous soil and corn silage nutrient concentrations and uptake. J. Environ. Qual. 2012, 41, 1033-1043. [CrossRef] [PubMed]

60. Novak, J.M.; Lima, I.; Xing, B.; Gaskin, J.W.; Steiner, C.; Das, K.; Ahmedna, M.; Rehrah, D.; Watts, D.W.; Busscher, W.J. Characterization of designer biochar produced at different temperatures and their effects on a loamy sand. Ann. Agric. Sci. 2009, 3, 195-206.

61. Roberts, T.L. Improving nutrient use efficiency. Turk. J. Agric. For. 2008, 32, 177-182.

62. Uzoma, K.C.; Inoue, M.; Andry, H.; Fujimaki, H.; Zahoor, A.; Nishihara, E. Effect of cow manure biochar on maize productivity under sandy soil condition. Soil Use Manag. 2011, 27, 205-212. [CrossRef]

63. Foti, C.; Khah, E.M.; Pavli, O.I. Germination profiling of lentil genotypes subjected to salinity stress. Plant Biol. 2019, 21, 480-486. [CrossRef]

64. Prendergast-Miller, M.T.; Duvall, M.; Sohi, S.P. Localisation of nitrate in the rhizosphere of biochar-amended soils. Soil Biol. Biochem. 2011, 43, 2243-2246. [CrossRef]

65. Tsai, W.-T.; Hsu, C.-H.; Lin, Y.-Q. Highly porous and nutrients-rich biochar derived from dairy cattle manure and its potential for removal of cationic compound from water. Agriculture 2019, 9, 114. [CrossRef]

66. Arya, L.M.; Paris, J.F. A physicoempirical model to predict the soil moisture characteristic from particle-size distribution and bulk density data 1. Soil Sci. Soc. Am. J. 1981, 45, 1023-1030. [CrossRef]

67. Lehmann, J.; Pereira da Silva, J.; Steiner, C.; Nehls, T.; Zech, W.; Glaser, B. Nutrient availability and leaching in an archaeological anthrosol and a ferralsol of the central amazon basin: Fertilizer, manure and charcoal amendments. Plant Soil 2003, 249, 343-357. [CrossRef]

68. Laird, D.; Fleming, P.; Wang, B.; Horton, R.; Karlen, D. Biochar impact on nutrient leaching from a midwestern agricultural soil. Geoderma 2010, 158, 436-442. [CrossRef]

69. Cheng, C.H.; Lehmann, J.; Engelhard, M.H. Natural oxidation of black carbon in soils: Changes in molecular form and surface charge along a climosequence. Geochim. Cosmochim. Acta 2008, 72, 1598-1610. [CrossRef]

70. Suppadit, T.; Kitikoon, V.; Phubphol, A.; Neumnoi, P. Effect of quail litter biochar on productivity of four new physic nut varieties planted in cadmium-contaminated soil. Chil. J. Agric. Res. 2012, 72, 125-132. [CrossRef]

71. Hossain, M.K.; Strezov, V.; Chan, K.Y.; Nelson, P.F. Agronomic properties of wastewater sludge biochar and bioavailability of metals in production of cherry tomato (lycopersicon esculentum). Chemosphere 2010, 78, 1167-1171. [CrossRef] [PubMed] 
72. Schmidt, M.W.I.; Noack, A.G. Black carbon in soils and sediments: Analysis, distribution, implications, and current challenges. Glob. Biogeochem. Cycle 2000, 14, 777-793. [CrossRef]

73. O'Toole, A.; Moni, C.; Weldon, S.; Schols, A.; Carnol, M.; Bosman, B.; Rasse, D.P. Miscanthus biochar had limited effects on soil physical properties, microbial biomass, and grain yield in a four-year field experiment in norway. Agriculture 2018, 8, 171. [CrossRef]

74. Speratti, A.B.; Romanyà, J.; Garcia-Pausas, J.; Johnson, M.S. Determining the stability of sugarcane filtercake biochar in soils with contrasting levels of organic matter. Agriculture 2018, 8, 71. [CrossRef]

75. Danish, S.; Zafar-ul-Hye, M. Co-application of acc-deaminase producing pgpr and timber-waste biochar improves pigments formation, growth and yield of wheat under drought stress. Sci. Rep. 2019, 9, 5999. [CrossRef] [PubMed]

(C) 2019 by the authors. Licensee MDPI, Basel, Switzerland. This article is an open access article distributed under the terms and conditions of the Creative Commons Attribution (CC BY) license (http://creativecommons.org/licenses/by/4.0/). 